https://www.altspu.ru/about_the_university/news/1 3193/ (20.04.2021).

14. Щербакова Ю. Б. Личная коллекция учителя Т. Г. Митьковской в собрании музея истории образования им. П. П. Костенкова //Сохранение и изучение культурного наследия Алтайского края. Барнаул, 2021. Вып. XXVII. C. 429-433.

15. Судьба и Родина едины // Алтайский государственный педагогический университет. URL: // https://www.old.altspu.ru/mc/mc_action/page/2/ (20.03.2021).

16. К 80-летию АКИПКРО // Алтайский государственный педагогический университет.
URL: // https://www.old.altspu.ru/mc/mc_library/28250-k-80-letiyu-akipkro.html/ (21.03.2021).

17. Фотовыставка «Учителя в Великой Отечественной войне» в АлтГПУ // Алтайский государственный педагогический университет. URL: // https://www.old.altspu.ru/mc/mc_action/ 31127-fotovystavka-uchitelya-v-velikoy-otechestvennoy-voyne-v-altgpu.html (20.02.2021).

18. Как мы провели «Ночь музеев» // Алтайский государственный педагогический университет. URL: // https://www.old.altspu.ru/mc /mc_action/32262-kak-my-proveli-noch-muzeev2021.html (20.03.2021).

УДК 379.852(571.15): 659.125.37+291.13(571.15)

DOI: $10.32340 / 2514-772 X-2021-1-67-71$

В. С. Яговец, доцент

Алтайский государственный институт культуры (Барнаул, Россия) viton@inbox.ru

Н. Н. Беспалова, кандидат педагогических наук, доцент Алтайский государственный институт культуры (Барнаул, Россия) natalya.bespalova.92@mail.ru

\title{
ИСПОЛЬЗОВАНИЕ ИСТОРИКО-КУЛЬТУРНОГО ПОТЕНЦИАЛА ТЕРРИТОРИИ В ТУРИСТИЧЕСКОМ МИФОТВОРЧЕСТВЕ (НА ПРИМЕРЕ АЛТАЙСКОГО КРАЯ)
}

Аннотация: В статье рассматриваются вопросы, связанные с использованием историкокультурного потенциала территории в таком туристическом явлении как мифотворчество. Мифология пространства является важнейшей частью культуры местного населения и влияет на формирование образа территории. Это, в свою очередь, отражается на восприятии данной территории посещающими ее туристами. Мифы, отображающие культурную специфику места, выражают его дух, который наряду с городскими легендами влияет на формирование географического образа, особую атмосферу места, его культурную идентичность, что в свою очередь, выступает решающим фактором при выборе места для совершения путешествия туристами. Авторы анализируют основные элементы мифологизации туристского пространства, различные виды классификаций мифов и принципы их создания. В статье также приводятся актуальные примеры создания мифов в сфере туризма на территории Алтайского края.

Ключевые слова: мифология пространства, мифотворчество в туризме, туристское легендирование, легендирование образа Барнаула, мифологизаџия пространства туристских территорий Алтайского края.

Современными исследователями замечено, что разум человека мифологичен и бессознательно соотносит объективную информацию об окружающем мире с субъективным опытом, собственными впечатлениями и фантазией. Мифологичность разума в процессе развития цивилизации использовалась стихийно или осознанно как в глобальном, так и в локальном масштабах.
Мифологизацию пространства исследователи определяют как «процесс генерации художественных образов на основе реальных свойств и событий, с этой территорией связанных» [1]. Основой для формирования мифологического пространства являются легенды, эпос, народные предания, художественный вымысел, устное народное творчество, рассказы очевидцев о мистических событиях и т. п. 
Мифология пространства является важнейшей частью культуры местного населения и влияет на формирование образа территории и, следовательно, на его туристический бренд. Наиболее яркие, аутентичные и целостные произведения становятся частью нематериального культурного наследия человечества, пополняя соответствующий список ЮНЕСКО.

Мифы, отображающие культурную специфику места, выражающие его дух, связаны с таким понятием, как гений места, который наряду с городскими легендами влияет на формирование географического образа. Гений места - это мифологический персонаж, художественный образ или реальный человек, создающий и оберегающий особую атмосферу места, его культурную идентичность. Согласно П. Вайлю «гений места выражается в неразрывной, но таинственной связи человека-творца с местом его обитания, обладающим особой неповторимой атмосферой». Яркими примерами этого являются Шерлок Холмс в Лондоне, Ромео и Джульетта в Вероне.

Многие исследователи в сфере туризма отмечают закономерность, и даже необходимость использования мифологизации для расширения туристского потенциала территории. Так, Е. А. Джанджугазова указывает, что «мифологическое пространство - это особый тип туристского пространства, основанный на искусственно созданных туристских аттракциях на основе мифологизации территории» [2].

Также для уточнения современного функционального назначения мифологизации используют другие термины. Например, П. С. Ширинкин [3] определяет: «туристское легендирование - это совокупность маркетинговых методов и приемов по созданию (выделению) легенды, «доращиванию» ее до категории бренда и доведению ее с помощью рекламы и пиара до потенциального и реального туриста». Целью туристского легендирования является подготовка благоприятных условий по созданию когнитивной системы образов, эффективно усваиваемых современными туристами для решения региональных управленческо-административных задач, связанных с развитием туризма на конкретной территории, а также по формированию у потенциальных потребителей-туристов устойчивой туристской мотивации, которая лежит в основе большинства путешествий.

Характерной чертой мифотворчества в туризме, особенно на современном этапе, является его тесная связь с мистикой. Иррациональное, сверхъестественное становится мощным фактором туристического развития отдельных территорий. Туристическая мифология, связанная с мистикой, может быть обоих указанных выше типов, то есть как выразителем культурной специфики места, так и сознательной мистификацией. Например, привидения в английских и шотландских замках - это часть национальной культуры Великобритании, нашедшая выражение в искусстве и литературе от Чарльза Диккенса до Оскара Уайльда. Естественно, и туризм эксплуатирует этот устоявшийся миф.

Среди других примеров туристической мифологизации можно выделить знаменитое озеро Лох-Несс в Шотландии, города Розуэлл (падение НЛО) и Салем (охота на ведьм) в США, Фатима (явление Девы Марии) в Португалии и многие другие места. В России этот процесс масштабно активизировался сравнительно недавно, но уже появилось немало интересных проектов (например, «Сказочная карта России»).

В научных изданиях в последние годы появилось немало статей, посвященных мифологизации и туристскому легендированию, приводятся примеры из практики, разрабатываются классификации (см. рис. 1), методики, технологии. На основе анализа различных источников можно выделить следующие признаки «правильного» туристского мифа:

- территориальная определенность;

- возможность визуализации

И транслирования;

- позитивный контекст (по возможности);

- актуальность для современной аудитории, доступность для понимания;

- эмоциональный мотив прикосновения к тайне, загадке;

- информационный шлейф, масштабность распространения;

- возможность использовать в турах, экскурсиях, туристских событиях, производстве сувенирной продукции;

- этичность, толерантность, отсутствие оскорблений.

Очевидны и требования к гидам, экскурсоводам и прочим «носителям мифологического наследия»: уметь отличать вымысел от достоверной, научно выверенной информации, иметь ссылки на первоисточники туристских мифов, не вводить в заблуждение туристов и экскурсантов относительно исторических фактов и окружающей среды. Особенно это касается организаторов «авторских экскурсий», которые, следуя спросу на сенсации и эксклюзив, уводят людей в безосновательную эзотерику и искажают реальность.

В данном аспекте А. Ю. Синцов предлагает выделять 2 типа мифов: 


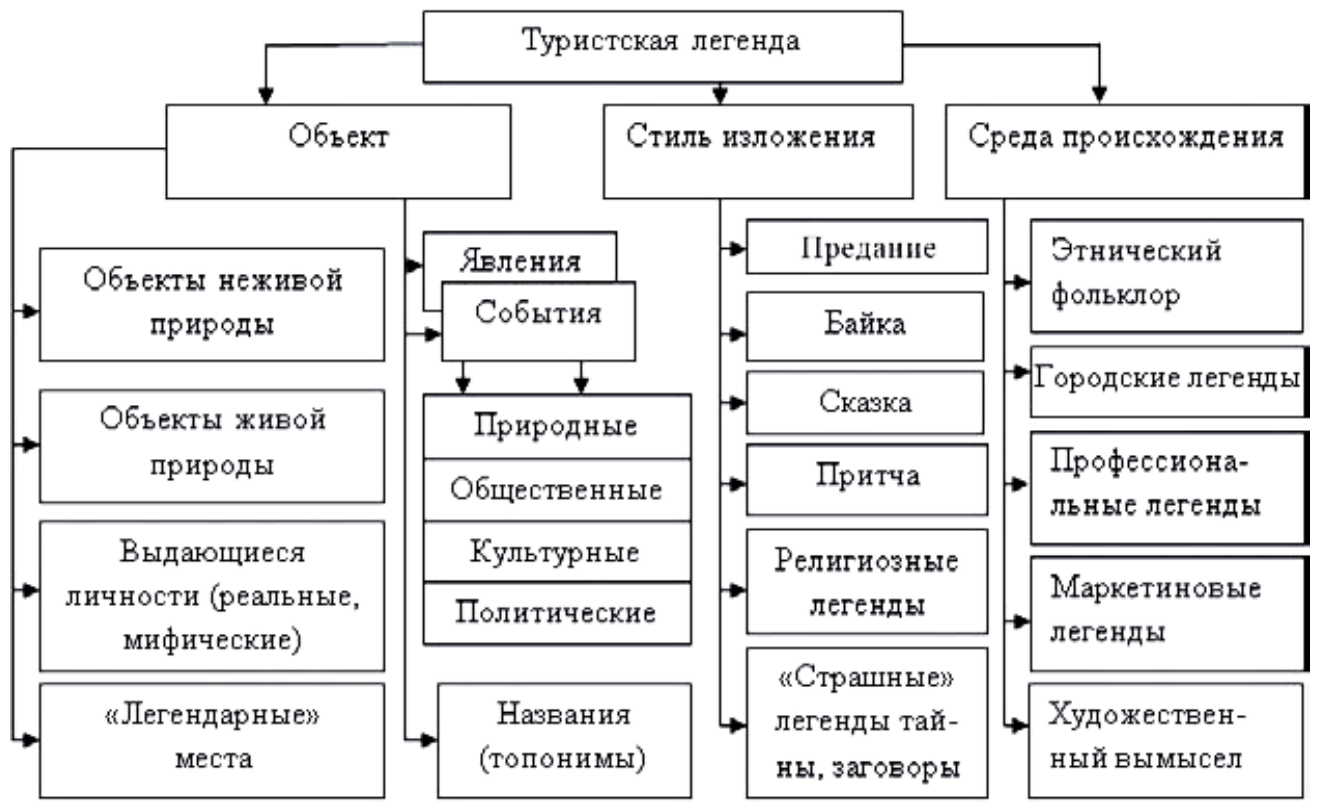

Рис. 1. Принципы классификации туристских легенд

(Афанасьев О. Е., Афанасьева А. В., 2015) [4].

1. Мифы, выражающие дух города, душу народа, относящиеся к ядру культуры, характеризующие ее сущность.

2. Мистификации, уводящие в сторону от сущности. Могут быть разных видов - например, то, что находится на периферии культуры, выдается за ядро, за ее главную характеристику. Также мистификации могут проявляться в виде сознательного искажения исторических фактов, топонимов, в виде подмены понятий с целью создания туристского интереса [5].

Таким образом, в настоящее время в использовании нематериального культурного наследия наблюдаются разнонаправленные тенденции: с одной стороны такие феномены становятся объектами изучения и охраны на самом высоком уровне (Список нематериального культурного наследия ЮНЕСКО) [6], с другой стороны, по мнению многих авторов «резко возросло внимание социума к локальному, курьезному, странному, аномальному - что связано с происходящей в эпоху постмодерна эволюцией культуры и общественной морали, изменением представлений о должном и допустимом и с радикальными изменениями в сфере массовых коммуникаций (резкое увеличение числа каналов распространения информации, снятие цензурных ограничений и др.)» [7].

Легендарный образ Барнаула начал формироваться достаточно давно. Вначале стихийно как народный фольклор, связанный с социальными и трудовыми отношениями на сереброплавильном заводе в XVIII-XIX вв. Затем в литературных произведениях А. М. Родионова,
М. И. Юдалевича и других о Демидове, Ползунове, Фролове, о беглеце Сороке, о «Голубой Даме». Следует отметить, что в XXI веке выпущено не так много литературы о Барнауле, в основном это фотоальбомы и небольшие путеводители. В последние годы одним из самых креативных и плодовитых писателеймифотворцев стал Василий Токмаков, благодаря произведениям которого некоторые рецензенты в блогах и соцсетях начали именовать Барнаул «мистической столицей России». На каналах РЕН-ТВ и НТВ отсняты достаточно интересные телефильмы о легендарном наследии Барнаула.

В сети Интернет создаются специальные сайты-«лэндинги» по легендам и былям Барнаула. На официальных сайтах барнаульских СМИ обязательно есть раздел о легендах и мифах города. Особенно большую роль в этом сыграл портал АМИК, на котором уже более 10 лет собирают городские легенды и были от краеведов и экспертов.

Пестрят барнаульскими легендами социальные сети, лайв-журналы. Даже на популярном российском туристском портале Russia.travel есть страница о барнаульских легендах. Наиболее популярными темами барнаульских легенд является наследие горнозаводской эпохи, в том числе самая известная «Легенда о Голубой даме», есть ряд легенд купеческого периода. В советское время, в силу специфики борьбы с заблуждениями, мифологизация скорее основывается на малоизвестных или засекреченных фактах, а вот в постсоветское время началось как возрождение старых легенд, так и 
создание абсолютно новых, нередко «фейковых» тематик (например, Барнаульский метрополитен). Барнаульские турфирмы также не обошли стороной популярную тему и в каталогах экскурсий у многих из них за последние годы появились тематические экскурсии и даже квесты с мистической сюжетной линией.

В последние годы городская администрация также озаботилась вопросом формирования образа, туристского бренда Барнаула. В рамках поддержанного федеральной целевой программой «Развитие внутреннего и въездного туризма в РФ» туркластера «Барнаул - горнозаводской город» появилась возможность профинансировать некоторые элементы туристского брендирования территории.

Был создан абсолютно новый образ на основе использования популярного Интернетмема «превед-медвед»: так появился новый логотип, новая легенда, снят видеоклип, поставлен уже полюбившийся горожанами и гостями артобъект «Дед-Медвед».

Однако не всем активистам и экспертам в городе эта идея пришлась по душе. Вероятно, это связано с определенным непониманием и зачастую несоответствием тех задач, которые были положены в основу концепции туркластера и реальным финансированием объектов. Экскурсионная практика показала, что новый туристский бренд Барнаула интересен лишь только детской аудитории.

Среди других туристских центров Алтайского края заметно выделяется мифологизации пространства в Бийском и Белокурихинском туристских районах, что вероятнее всего связано с активным спросом туристов на подобную информацию и креативом от местных экскурсоводов. Так, в Бийске была предпринята попытка стать сибирской столицей пельменя, для чего, в течение нескольких лет успешно организовывался чемпионат поспортивному пельменингу, в котором принимал участие ведущий телепередачи «Поедем, поедим!» Джон Уоррен. А по Чуйскому тракту неподалеку от родины В. М. Шукшина с. Сростки расположился один из ярких примеров мифологизации - этнокультурный парк «Легенда» и музей-панорама «Алтай. История России», созданный под руководством председателя общественной организации «Союз национальных культур Алтая» А. М. Игнатенко. Здесь можно непосредственно наблюдать визуализированный авторский вариант материализации нематериального культурного наследия Алтайского региона.
Также активно пополняется «мифологический арсенал» курорта федерального значения Белокуриха, благодаря творческим инициативам экскурсоводов и руководителя городского музея Белокурихи им. С. И. Гуляева Т. А. Батуевой. Практикующие экскурсоводы предлагают экскурсантам пять интригующих версий толкования названия «Белокуриха» и успешно проводят экскурсию под названием «Мистическая Белокуриха».

В мифологизации туристического пространства заметную роль играют «гении места», среди которых в Алтайском крае можно назвать В. М. Шукшина, М. Т. Калашникова, Г. С. Титова, М. С. Евдокимова, В. С. Золотухина. Вместе с тем, следует отметить, что наблюдается определенный «мифологический дефицит» в новых туристических зонах Алтая, таких как «Бирюзовая Катунь», «Белокуриха Горная», природный парк «Предгорья Алтая», курорт Яровое, спортивно-туристский кластер «Тягун». На наш взгляд, данные территории еще успеют «обрасти» различными мифами и легендами, которые привлекут внимание различного рода путешественников и туристов.

Таким образом, мифологизация туристского пространства на основе использования историко-культурного потенциала, является важнейшей частью культуры местного населения и влияет на формирование запоминающегося образа территории, что, в свою очередь, отражается на восприятии данной территории посещающими еe туристами. Мифы, отображающие культурную специфику места, выражают его дух, который наряду с городскими легендами, влияет на формирование географического образа, особую атмосферу места, его культурную идентичность, выступают решающими факторами при выборе места для совершения путешествия туристами. В связи с этим можно сделать вывод о том, что использование мифологизации пространства необходимо в целях расширения туристского потенциала любой территории, в том числе и Алтайского края.

\section{Список литературы}

1. Волкова Т. А., Карпова Ю. И., Мищенко $A$. И., Задорожняя В. В. Мифологизация рекреационного пространства как фактор освоения территории // Географические исследования Краснодарского края. Краснодар, 2012. С. 173177.

2. Джанджугазова Е. А. Туристско-рекреационное проектирование. Москва, 2014. 272 с. 
3. Ширинкин П. С. К вопросу об использовании символических средств и ресурсов в развитии гуманитарного потенциала территории // Философские науки. 2016. № 4 . С. 104-113.

4. Афанасьев О.Е., Афанасьева А.В. Функциональное значение и место туристских легенд в формировании привлекательных свойств дестинаций // Вестник ассоциации вузов туризма и сервиса. Том 9. 2015. № 1. C. $52-59$.

5. Синщов А. Ю. Мифология в туризме: опыт историко-культурологического анализа //
Вестник Казанского государственного университета культуры и искусств, 2016. С. 54-57.

6. Browse the Lists of Intangible Cultural Heritage and the Register of good safeguarding practices. URL: https://ich.unesco.org/en/lists (19.05.2021).

7. Леонов И. В., Кириллов И. В., Жаркова A. Г. «Новые традиции» как феномен современной туристической отрасли // Ученые записки (Алтайская государственная академия культуры и искусств). 2020. № 4 (26). С. 13-27. 